\title{
Passive and active earth pressures in the presence of groundwater flow
}

\author{
N. BENMEBAREK*, S. BENMEBAREK*, R. KASTNER† and A.-H. SOUBRA
}

This paper deals with the effect of seepage flow on the lateral earth pressures acting on deep sheeted excavations in cohesionless soil. The computation of the passive and active earth pressures in the presence of hydraulic gradients is performed using the explicit finite difference method implemented in Fast Lagrangian Analysis of Continua (FLAC) code. The available effective passive earth pressure coefficients in the presence of upward seepage forces are given for both associative and nonassociative material. The present solutions show that the soil dilation angle influences the effective passive earth pressures for large internal friction angle values of the soil. They also show that the effective passive pressures diminish with the hydraulic head loss. Good agreement is observed between the present results and those using an upper-bound approach in limit analysis for an associative material. For the active case, the effect of downward seepage forces on the active earth pressures is investigated. The numerical results show a significant increase in the effective active earth pressures due to a hydraulic head loss. It is also shown that the dilation angle influences the effective active earth pressures for large internal friction angle values.

KEYWORDS: earth pressure; numerical modelling and analysis; piles; pore pressures; sands; seepage
Cet exposé est consacré aux effets des infiltrations sur les pressions terrestres latérales agissant sur les excavations à feuilles profondes dans des sols non cohésifs. Nous calculons les pressions terrestres actives et passives en présence de gradients hydrauliques en utilisant la méthode explicite de différence finie mise en oeuvre dans le code FLAC. Nous donnons les coefficients disponibles de pression terrestre passive effective en présence de forces d'infiltration remontantes pour les matières associatives et les matières non associatives. Les solutions données ici montrent que l'angle de dilatation du sol influence les pressions terrestres passives effectives pour les grandes valeurs d'angles de friction interne du sol. Elles montrent aussi que les pressions passives effectives diminuent avec la perte de hauteur hydraulique. On observe une bonne concordance entre ces résultats et ceux qui utilisent une méthode limite supérieure dans une analyse limite pour une matière associative. Pour le cas actif, nous avons étudié l'effet des forces d'infiltration descendantes sur les pressions terrestres actives. Les résultats numériques montrent une augmentation significative des pressions terrestres actives effectives en raison d'une perte de la hauteur hydraulique. Nous montrons aussi que l'angle de dilatation influence les pressions terrestres actives effectives pour les grandes valeurs d'angle de friction interne.

\section{INTRODUCTION}

Deep sheeted excavations are commonly encountered in the practice of geotechnical engineering. The major factor that influences the design of such structures is the flow of water around the sheet piles. The seepage flow influences the overall stability of the wall and the stability of the excavation where bulk heave or piping may occur. A further factor to be considered in the design of these structures is the rate of seepage into the excavation.

The determination of the rate of seepage flow into an excavation has been considered by several authors in the literature. In the past, design charts for steady seepage into cofferdams were presented on the basis of numerical solutions (Fox \& McNamee, 1948; McNamee, 1949) and physical modelling (Marsland, 1953). Analytical solutions have been sought by several researchers. The problem of seepage into a cofferdam in an infinitely deep stratum, and into an infinitely wide double-walled system, was developed by Harr \& Deen (1961) and Harr (1962) respectively. The problem of seepage into a cofferdam in a pervious stratum of finite depth was presented by King \& Cockroft (1972), Banerjee \& Muleshkov (1992) and Banerjee (1993).

\footnotetext{
* Civil Engineering Laboratory, Biskra University, Algeria.

$\dagger$ URGC Géotechnique, Institut National des Sciences Appliquées de Lyon, France.

† University of Nantes, IUP Génie Civil et Infrastructures, SaintNazaire, France.
}

For the stability analysis of the excavation in the presence of seepage forces, most authors have defined a factor of safety with respect to failure by piping or heaving. On the other hand, the analysis of wall stability requires the evaluation of the reduction in available passive soil resistance and of the increase in active soil pressure due to seepage. The approximate practical rule employed by geotechnical engineers considers the traditional active and passive earth pressure coefficients, and makes use of an apparent soil unit weight $\gamma_{\mathrm{app}}^{\prime}=\gamma^{\prime} \pm i \gamma_{\mathrm{w}}$ with the upper sign for downward seepage flow, where $\gamma^{\prime}$ is the submerged unit weight of the soil, $\gamma_{\mathrm{w}}$ is the unit weight of water, and $i$ is the average hydraulic gradient along the wall.

This paper focuses on the evaluation of the reduction in passive earth pressures and the increase in active earth pressures in the presence of hydraulic gradients. After a brief review of the literature on the stability of deep sheeted excavations subject to seepage forces, a description of the numerical simulations of passive and active earth pressures taking into consideration the seepage forces follows. An interpretation and discussion of the numerical results obtained from the present analysis conclude this paper.

\section{INFLUENCE OF GROUNDWATER FLOW ON STABILITY OF DEEP SHEETED EXCAVATIONS}

The influence of seepage flow on the stability of deep sheeted excavations was first addressed by Terzaghi (1943). From model tests he found that, within an excavation, the zone of danger of bottom heave is confined to a soil prism adjacent to the wall. For a row of sheet piles in an isotropic soil, the depth of the prism subject to upheaval is equal to 
the depth of pile penetration, and the width is one half of the wall penetration depth. The factor of safety against bulk heave is determined by the ratio between the submerged weight of the prism and the corresponding upward vertical seepage force. It should be mentioned that Terzaghi's approach neglects the vertical frictional forces along the vertical faces of the soil prism.

McNamee (1949) identified two main types of failure: local failure and general upheaval. Local failure is most likely to begin at a point on the surface adjacent to the sheet pile, as it lies within the shortest seepage path. He termed local failure as failure by piping or boiling, and the more widespread type of failure as heaving.

Marsland (1953) undertook extensive model tests using both dense and loose homogeneous sands in an open water excavation. He concluded that, in loose sand, failure occurs when the pressure at the pile tip is sufficient to lift the column of submerged sand near the wall of the cofferdam; in dense sand, failure occurs when the exit gradient at the excavation surface reaches a critical value.

Bazant (1963) established a failure criterion with regard to the shear strength of the soil by plotting the excess hydrostatic pressure at the pile tip divided by the embedment depth of the pile against the internal friction angle of the soil.

Davidenkoff \& Franke (1965) proposed a diagram based on model studies that can be used to determine the factor of safety against piping for excavations in open water with different thicknesses of the pervious stratum.

Kastner (1982) conducted laboratory model tests and concluded that the failure of the sheet piles is not only due to piping or heaving but may also occur as a result of the reduction of the passive earth pressures in front of the wall. Based on this experimental evidence, Soubra et al. (1999) elaborated a theoretical model for the calculation of the effective passive earth pressure coefficients, taking the seepage forces into consideration. Their model is based on the variational limit equilibrium method. These authors have shown that their method is equivalent to the upper-bound method in limit analysis, and therefore their solutions are upper bounds with respect to the exact solutions for an associative material.

Our aim in this paper is to propose numerical solutions for both passive and active earth pressures, taking the seepage forces into account and using the explicit finite difference method implemented in Fast Lagrangian Analysis of Continua (FLAC) code (Itasca, 2000). Solutions are given for both associative $(\psi=\phi)$ and non-associative $(\psi<\phi)$ material.

\section{FLAC SIMULATIONS FOR COMPUTATION OF EARTH} PRESSURES IN PRESENCE OF GROUNDWATER FLOW

Figure 1 shows a single sheet pile wall driven in a semiinfinite homogeneous and isotropic cohesionless soil.

The numerical FLAC simulations attempt to predict the effective passive and active earth pressures acting on the sheet pile wall in the presence of a hydraulic head loss $H$ (see Fig. 1). After a brief description of FLAC code, the numerical simulations are described.

FLAC is a commercially available finite difference program based on an explicit Lagrangian calculation scheme. In this scheme the solution to a static problem is obtained as the result of damping of a dynamic process in which the equations of motion are used. The stresses and deformations are calculated at several small time steps until a steady state (either equilibrium or plastic flow) is achieved in a numerically stable way with the minimal computational effort. The convergence to this state may be controlled by a maximal

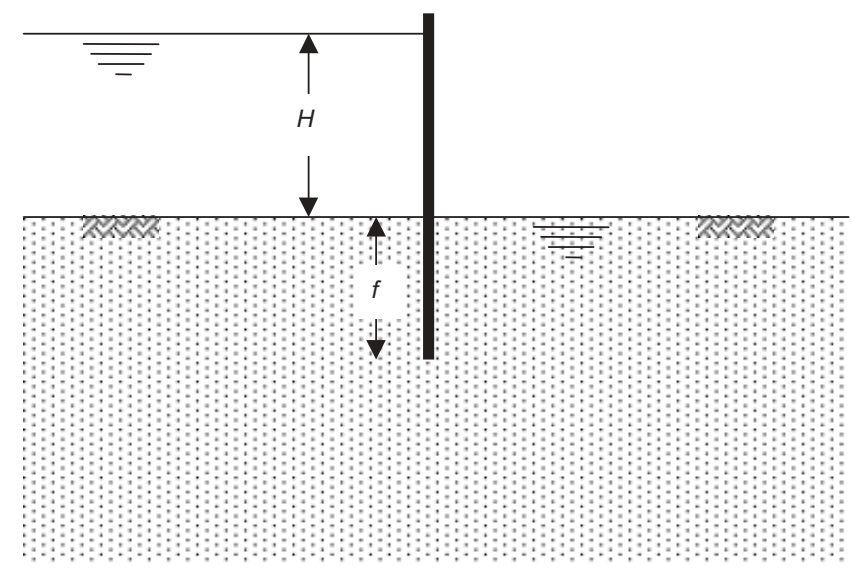

Fig. 1. Case study

prescribed value of the unbalanced force for all elements of the model. The time steps, smaller than a critical value for stability, are automatically defined by FLAC and are functions of the elements' size and materials' stiffness. This prevents divergence of the explicit resolution scheme. In FLAC's formulation no iteration process is used when computing stresses from strains in an element during one solution step, even if the constitutive law is wildly nonlinear. This is because no algorithm is necessary to bring the stress of each element to the yield surface: the plasticity equations are solved exactly in one step. By contrast, in the implicit method, commonly used in finite element programs, several iterations are necessary before compatibility and equilibrium are obtained for the case of the steady plasticflow state.

FLAC code is suitable for ill-behaved systems (non-linear, large strain, physical instability) and is not efficient for modelling linear problems. The program includes an internal programming option (FISH), which enables the user to define quantities to be calculated and to control the analysis process.

Figure 2 shows the mesh and mechanical boundary conditions for this analysis. The model region was divided into 3200 elements. The element size was fine near the wall where deformations and flow gradients are concentrated.

The vertical and bottom boundaries were respectively located at a distance six and five times the wall penetration in order to minimise boundary effects. The bottom boundary was assumed to be fixed, and the vertical boundaries were constrained in motion in the horizontal direction.

The retaining wall was modelled by 20 structural beam elements connected to the soil grid via interface elements attached on both sides of the beam elements. The wall thus acts as an impermeable member.

The experimentally observed non-associativity of the soil quantified by the dilation angle $\psi$ is accounted for in the

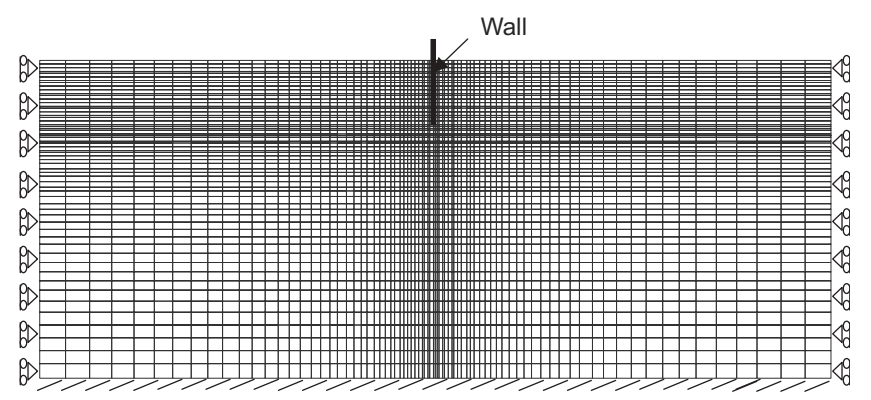

Fig. 2. Mesh used in FLAC simulations 
calculations. The elastic-perfectly plastic, non-associative Mohr-Coulomb model encoded in FLAC was used. The elastic bulk modulus $K=60 \mathrm{MPa}$ and shear modulus $G=$ $22.5 \mathrm{MPa}$ were assumed. The interface elements used to connect the soil grid to the wall beam elements were described by the Coulomb law. The interface has friction angle $\delta$, cohesion $c=0 \mathrm{kPa}$, normal stiffness $K_{\mathrm{n}}=10^{9} \mathrm{~Pa} /$ $\mathrm{m}$, and shear stiffness $K_{\mathrm{s}}=10^{9} \mathrm{~Pa} / \mathrm{m}$. Four values of the angle of internal friction $\left(\phi=20^{\circ}, 30^{\circ}, 35^{\circ}, 40^{\circ}\right)$, three values of the friction angle at the soil/wall interface $(\delta / \phi=$ $0,1 / 3,2 / 3)$, and three values of the dilation angle $(\psi / \phi=0$, $1 / 2,2 / 3$ or 1 ) were considered in the analysis. All subsequent results are given for $\gamma_{\mathrm{sat}} / \gamma_{\mathrm{w}}=2$.

Three steps are necessary for simulation of the effective passive or active earth pressures. In the first step the initial pore water pressures and the initial effective stresses were established assuming that

(a) the groundwater level is located at the ground surface on both sides of the sheet pile (i.e. there is no seepage flow during this stage)

(b) the ratio of effective horizontal stress to effective vertical stress at rest is $0 \cdot 5$.

At this stage some stepping is required to bring the model to equilibrium. This is because additional stiffnesses from the structural beam elements representing the wall and interface elements produce an imbalance that necessitates some stepping to equilibrate the model.

Second, a hydraulic head loss $H$ was applied to the sheet pile wall, as shown in Fig. 1. The corresponding boundary conditions in terms of pore water pressures are shown in Fig. 3. The field describing the distribution of pore water pressures was calculated using the groundwater flow option in FLAC. This hydraulic field is assumed unchanged during the indentation process described in the following paragraph. This means that the soil is assumed to be sufficiently permeable to avoid any excess pore water pressures in the soil.

In the third step, to represent rigid wall translation, a controlled horizontal velocity was applied to the wall nodes. Using a FISH function, the earth pressure forces (active or passive) acting on both sides of the wall can be calculated as the integral of stress components for all elements in contact with the wall. The kinematically controlled indentation of the wall was modelled in several steps. First, a relatively high velocity of $10^{-6} \mathrm{~m} / \mathrm{step}$ was applied to the wall. This first stepping was applied until a steady plasticflow state was achieved (i.e. until both conditions (a) a constant earth pressure force and (b) small values of unbalanced forces were obtained as the number of cycles increased). As the level of error in such a FLAC calculation scheme depends on the applied velocity, a more accurate earth pressure force can be obtained by reducing the wall

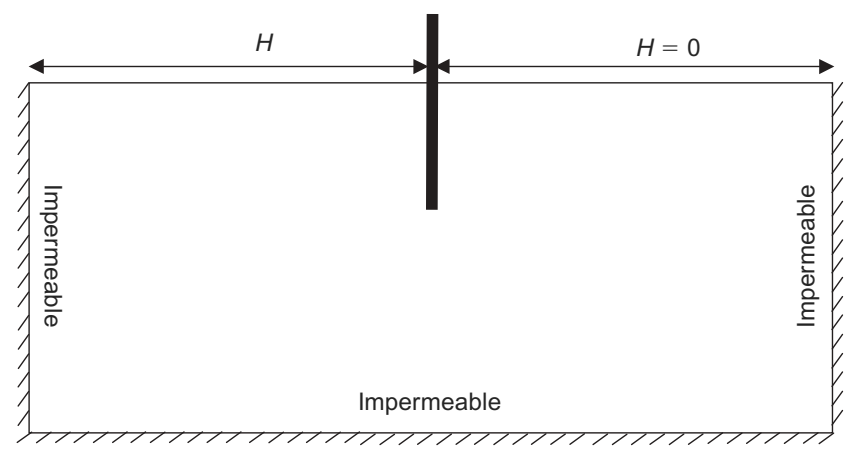

Fig. 3. Hydraulic boundary conditions velocity by half, and continuing to a new steady plastic-flow state. This procedure, recommended by the FLAC manual, was repeated several times, particularly for soils with large values of the internal friction angle and large values of the dilatancy angle, until the difference between the earth forces (active or passive) calculated at two successive steady plastic-flow states becomes smaller than $0 \cdot 5 \%$. Such a numerical modelling method to obtain the ultimate load has been previously reported in the literature for the case of bearing capacity prediction (Erickson \& Dresher, 2002). A parametric study showed that this solution, obtained by a sequential reduction of the velocity of the wall was very close to a solution where the indentation was performed with a very low constant velocity $\left(10^{-8} \mathrm{~m} / \mathrm{step}\right)$ throughout the whole indentation process. However, the reduction of the computational time is significant.

\section{NUMERICAL RESULTS}

Seepage flow has the unfavourable effects of increasing active and reducing passive lateral earth pressures. Hence the assessment of changes in lateral earth pressures as the result of a seepage flow is of practical significance in most designs of deep sheeted excavations. The solutions obtained in both passive and active cases are presented and discussed.

\section{Passive case}

Figure 4 shows the variation of the horizontal component of the effective passive force with the wall horizontal displacement for $\phi=40^{\circ}, \delta / \phi=2 / 3, H / f=1$ and for three values of the dilation angle $\psi / \phi=0,1 / 2,2 / 3$.

The asymptotic limiting value corresponds to the maximum effective passive earth force $P_{\mathrm{p}_{x}}^{\prime}$ that could be mobilised. The control of the interface shear displacements showed that the prescribed value of wall friction angle was fully mobilised everywhere around the wall. Hence the passive earth pressure coefficient $K_{\mathrm{p}}$ can be deduced from

$$
P_{\mathrm{p}_{x}}^{\prime}=P_{\mathrm{p}}^{\prime} \cos \delta=K_{\mathrm{p}} \frac{\gamma^{\prime} f^{2}}{2} \cos \delta
$$

Figure 5 shows the distribution of the effective passive earth pressures acting along the wall for $\phi=40^{\circ}, \psi=20^{\circ}$, $H / f=1$ and for three values of the interface friction angle $\delta / \phi=0,1 / 3,2 / 3$. This figure also shows the pore water pressure distribution.

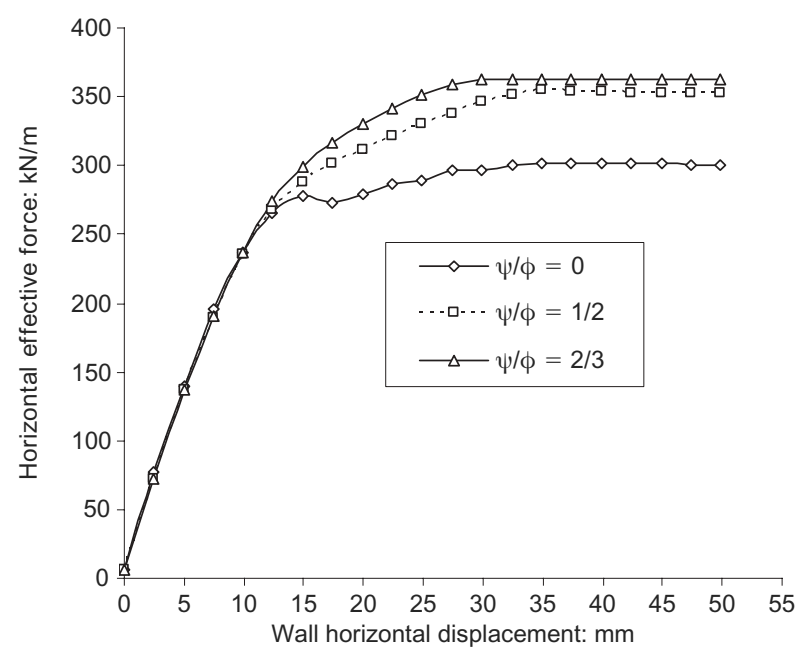

Fig. 4. Horizontal effective force against wall horizontal displacement for $\phi=40^{\circ}, \delta / \phi=2 / 3, H / f=1$ and for three $\psi / \phi$ values 


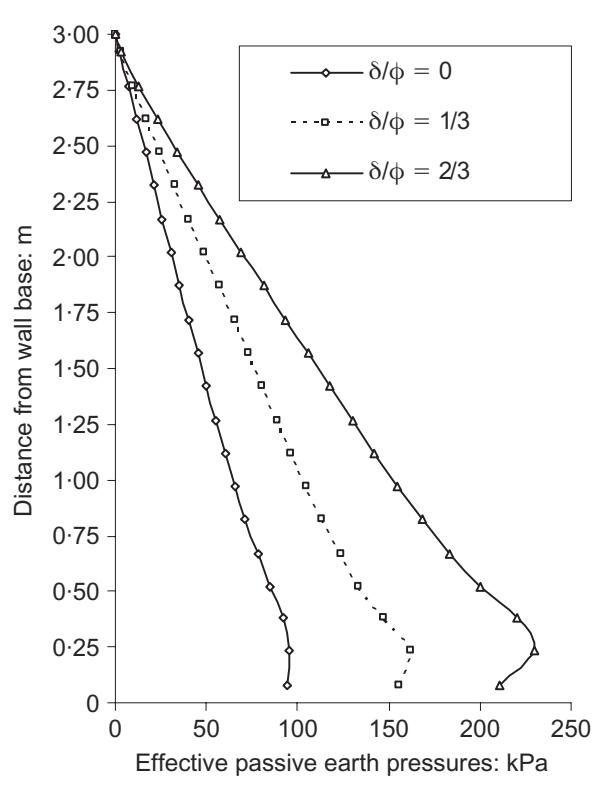

(a)

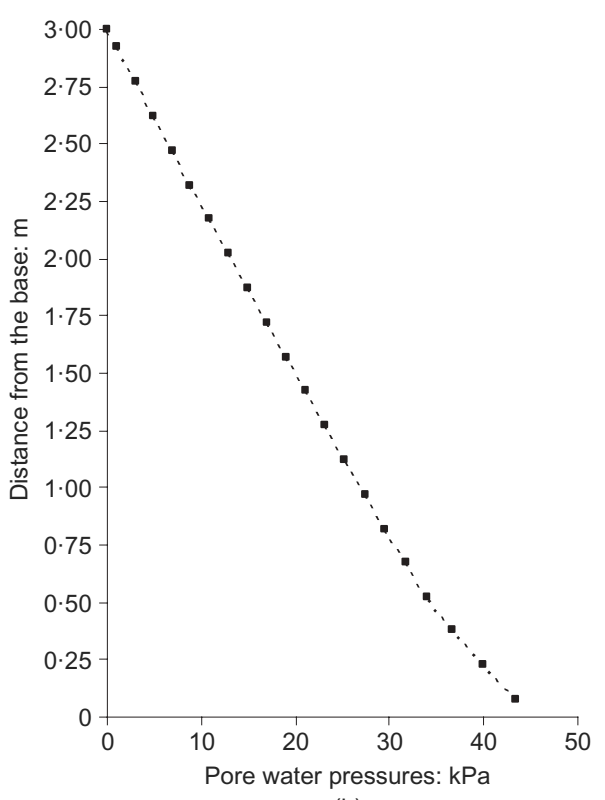

(b)

Fig. 5 Distribution of (a) effective passive earth pressures and (b) pore water pressures along the wall for $\phi=40^{\circ}, \psi=20^{\circ}, H / f=1$ and for three $\delta / \phi$ values

Apart from a curvature at the bottom third of the wall for $\delta / \phi=2 / 3$, the effective passive earth pressure diagram is linear. This distribution is in conformity with the translational wall movement. On the other hand, the pore water pressures are greater than the hydrostatic ones owing to the upward seepage forces, especially at the bottom of the wall where the hydraulic gradients are significant.
In the following, we present and discuss in succession

(a) the passive earth pressure coefficient $K_{\mathrm{p}}$ for no seepage flow $(H / f=0)$

(b) the passive earth pressure coefficient in the presence of seepage flow for various values of the governing parameters $\phi, \delta / \phi, \psi / \phi$ and $H / f$.

Table 1. Comparison of present $K_{\mathrm{p}}$ coefficient with other existing solutions when $\delta / \phi=1$

\begin{tabular}{l|c|c|c|c}
\hline$\phi:$ degrees & Present solution, $\psi=\phi$ & Caquot \& Kérisel (1948) & Soubra (2000) & Soubra \& Macuh (2002) \\
\hline 20 & $3 \cdot 01$ & $3 \cdot 10$ & $3 \cdot 12$ & $3 \cdot 13$ \\
30 & $6 \cdot 33$ & $6 \cdot 5$ & $6 \cdot 86$ & 6.93 \\
35 & $10 \cdot 10$ & $10 \cdot 5$ & $11 \cdot 13$ & $11 \cdot 3$ \\
40 & - & 18 & $19 \cdot 62$ & $20 \cdot 01$ \\
\hline
\end{tabular}

Table 2. Passive earth pressure coefficient $K_{\mathrm{p}}$ for various governing parameters $\phi, \psi / \phi$, and $H / f$ when $\delta / \phi=0$

\begin{tabular}{|c|c|c|c|c|c|c|c|c|c|}
\hline \multirow[t]{3}{*}{$\phi:$ degrees } & \multirow[t]{3}{*}{$\psi / \phi$} & \multicolumn{8}{|c|}{$H / f$} \\
\hline & & \multicolumn{2}{|c|}{0} & \multicolumn{2}{|c|}{1} & \multicolumn{2}{|c|}{2} & \multicolumn{2}{|c|}{$2 \cdot 5$} \\
\hline & & FLAC & S & FLAC & S & FLAC & $\mathrm{S}$ & FLAC & S \\
\hline 20 & $\begin{array}{r}0 \\
1 / 2 \\
1\end{array}$ & $\begin{array}{l}2 \cdot 06 \\
2 \cdot 07 \\
2 \cdot 07\end{array}$ & $2 \cdot 04$ & $\begin{array}{l}1.36 \\
1.37 \\
1.37\end{array}$ & $1 \cdot 35$ & $\begin{array}{l}0.63 \\
0.63 \\
0.63\end{array}$ & $0 \cdot 65$ & $\begin{array}{l}0 \cdot 26 \\
0 \cdot 26 \\
0 \cdot 26\end{array}$ & $0 \cdot 28$ \\
\hline 30 & $\begin{array}{r}0 \\
1 / 2 \\
1\end{array}$ & $\begin{array}{l}2.98 \\
3.04 \\
3.06\end{array}$ & $3 \cdot 00$ & $\begin{array}{l}2 \cdot 01 \\
2 \cdot 09 \\
2 \cdot 10\end{array}$ & 2.04 & $\begin{array}{l}1.03 \\
1.06 \\
1.06\end{array}$ & 1.06 & $\begin{array}{l}0.51 \\
0.52 \\
0.52\end{array}$ & 0.54 \\
\hline 35 & $\begin{array}{r}0 \\
1 / 2 \\
1\end{array}$ & $\begin{array}{l}3.54 \\
3.75 \\
3.76\end{array}$ & $3 \cdot 69$ & $\begin{array}{l}2 \cdot 43 \\
2 \cdot 58 \\
2 \cdot 60\end{array}$ & $2 \cdot 55$ & $\begin{array}{l}1.29 \\
1.39 \\
1.40\end{array}$ & $1 \cdot 38$ & $\begin{array}{l}0 \cdot 70 \\
0 \cdot 74 \\
0 \cdot 75\end{array}$ & 0.75 \\
\hline 40 & $\begin{array}{r}0 \\
1 / 2 \\
2 / 3\end{array}$ & $\begin{array}{l}4 \cdot 04 \\
4 \cdot 67 \\
4 \cdot 69\end{array}$ & $4 \cdot 60$ & $\begin{array}{l}2 \cdot 97 \\
3 \cdot 27 \\
3 \cdot 30\end{array}$ & $3 \cdot 23$ & $\begin{array}{l}1.61 \\
1.81 \\
1.83\end{array}$ & $1 \cdot 82$ & $\begin{array}{l}0.91 \\
1.05 \\
1.06\end{array}$ & 1.06 \\
\hline
\end{tabular}

$\mathrm{S}=$ after Soubra et al. (1999). 
For the case of no seepage flow, there are a great many solutions in the literature based on

(a) the limit equilibrium method (Shields \& Tolunay, 1972, 1973; Rahardjo \& Fredlund, 1984)

(b) the slip-line method (Caquot \& Kérisel, 1948; Sokolovski, 1965; Graham, 1971)

(c) limit analysis theory (Lysmer, 1970; Chen \& Liu, 1990; Soubra, 2000; Soubra \& Macuh, 2002).

The tendency in practice is to use the values given by Caquot \& Kérisel (1948) (cf. tables of Kérisel \& Absi, 1990). Table 1 shows a comparison of the present solutions for $\psi=\phi$ with those of Caquot \& Kérisel (1948), Soubra (2000) and Soubra \& Macuh (2002) when $\delta / \phi=1$.

The present results are close to the currently used values of Caquot and Kérisel and the upper-bound solutions given by Soubra (2000) using a translational failure mechanism and Soubra \& Macuh (2002) using a rotational failure mechanism. It should be noted that numerical instabilities were observed for large values of the internal friction angle and fully dilatant soil $\left(\phi=\psi \geqslant 40^{\circ}\right)$. This effect has been reported in the literature for bearing capacity prediction (Itasca, 2000; Frydman \& Burd, 1997).

To investigate how the passive earth pressure coefficient is affected by the groundwater flow, Tables 2, 3 and 4 give the present effective passive earth pressure coefficient $K_{\mathrm{p}}$ for three different values of the interface friction angle: $\delta / \phi=$ $0,1 / 3$ or $2 / 3$. In each table the passive earth pressure coefficient is given for four values of the friction angle $(\phi$ $=20^{\circ}, 30^{\circ}, 35^{\circ}, 40^{\circ}$ ), for three values of the dilation angle $(\psi / \phi=0,1 / 2,2 / 3$ or 1$)$ and for four values of the hydraulic head loss $(H / f=0,1,2,2 \cdot 5)$. In a previous paper Soubra et al. (1999) considered a rotational log-spiral failure mechanism to assess the available effective passive earth pressures in the presence of a groundwater flow using the kinematical approach of limit analysis theory. The solutions given by Soubra et al. (1999) are also reported in Tables 2, 3 and 4 for comparison with the present results in the case $\psi=\phi$. This comparison shows good agreement; the difference does not exceed $9 \%$.

Table 3. Passive earth pressure coefficient $K_{\mathrm{p}}$ for various governing parameters $\phi, \psi / \phi$, and $H / f$ when $\delta / \phi=1 / 3$

\begin{tabular}{|c|c|c|c|c|c|c|c|c|c|}
\hline \multirow[t]{3}{*}{$\phi:$ degrees } & \multirow[t]{3}{*}{$\psi / \phi$} & \multicolumn{8}{|c|}{$H / f$} \\
\hline & & \multicolumn{2}{|c|}{0} & \multicolumn{2}{|c|}{1} & \multicolumn{2}{|c|}{2} & \multicolumn{2}{|c|}{$2 \cdot 5$} \\
\hline & & FLAC & S & FLAC & $\mathrm{S}$ & FLAC & $\mathrm{S}$ & FLAC & S \\
\hline 20 & $\begin{array}{r}0 \\
1 / 2 \\
1\end{array}$ & $\begin{array}{l}2 \cdot 39 \\
2 \cdot 39 \\
2 \cdot 39\end{array}$ & $2 \cdot 38$ & $\begin{array}{l}1.61 \\
1.61 \\
1.61\end{array}$ & $1 \cdot 60$ & $\begin{array}{l}0.77 \\
0.78 \\
0.78\end{array}$ & $0 \cdot 80$ & $\begin{array}{l}0 \cdot 39 \\
0 \cdot 39 \\
0 \cdot 39\end{array}$ & $0 \cdot 37$ \\
\hline 30 & $\begin{array}{r}0 \\
1 / 2 \\
1\end{array}$ & $\begin{array}{l}3.98 \\
4.03 \\
4.03\end{array}$ & $4 \cdot 03$ & $\begin{array}{l}2 \cdot 81 \\
2 \cdot 82 \\
2 \cdot 82\end{array}$ & $2 \cdot 81$ & $\begin{array}{l}1.51 \\
1.52 \\
1.53\end{array}$ & $1 \cdot 54$ & $\begin{array}{l}0 \cdot 82 \\
0 \cdot 84 \\
0 \cdot 84\end{array}$ & $0 \cdot 87$ \\
\hline 35 & $\begin{array}{r}0 \\
1 / 2 \\
1\end{array}$ & $\begin{array}{l}5 \cdot 10 \\
5 \cdot 41 \\
5 \cdot 42\end{array}$ & $5 \cdot 44$ & $\begin{array}{l}3 \cdot 83 \\
3 \cdot 85 \\
3 \cdot 87\end{array}$ & $3 \cdot 87$ & $\begin{array}{l}2 \cdot 19 \\
2 \cdot 22 \\
2 \cdot 22\end{array}$ & $2 \cdot 26$ & $\begin{array}{l}1.29 \\
1.34 \\
1.34\end{array}$ & $1 \cdot 39$ \\
\hline 40 & $\begin{array}{r}0 \\
1 / 2 \\
2 / 3\end{array}$ & $\begin{array}{l}6.35 \\
7.50 \\
7.53\end{array}$ & $7 \cdot 62$ & $\begin{array}{l}4.95 \\
5 \cdot 52 \\
5 \cdot 55\end{array}$ & $5 \cdot 57$ & $\begin{array}{l}3 \cdot 27 \\
3.53 \\
3.56\end{array}$ & $3 \cdot 74$ & $\begin{array}{l}2 \cdot 19 \\
2 \cdot 21 \\
2 \cdot 24\end{array}$ & $2 \cdot 30$ \\
\hline
\end{tabular}

$\mathrm{S}=$ after Soubra et al. (1999).

Table 4. Passive earth pressure coefficient $K_{\mathrm{p}}$ for various governing parameters $\phi, \psi / \phi$, and $H / f$ when $\delta / \phi=2 / 3$

\begin{tabular}{|c|c|c|c|c|c|c|c|c|c|}
\hline \multirow[t]{3}{*}{$\phi:$ degrees } & \multirow[t]{3}{*}{$\psi / \phi$} & \multicolumn{8}{|c|}{$H / f$} \\
\hline & & \multicolumn{2}{|c|}{0} & \multicolumn{2}{|c|}{1} & \multicolumn{2}{|c|}{2} & \multicolumn{2}{|c|}{$2 \cdot 5$} \\
\hline & & FLAC & S & FLAC & $\mathrm{S}$ & FLAC & S & FLAC & S \\
\hline 20 & $\begin{array}{r}0 \\
1 / 2 \\
1\end{array}$ & $\begin{array}{l}2 \cdot 72 \\
2 \cdot 72 \\
2 \cdot 72\end{array}$ & $2 \cdot 75$ & $\begin{array}{l}1.85 \\
1.86 \\
1.86\end{array}$ & 1.87 & $\begin{array}{l}0.94 \\
0.94 \\
0.94\end{array}$ & 0.96 & $\begin{array}{l}0.41 \\
0.41 \\
0.41\end{array}$ & $0 \cdot 47$ \\
\hline 30 & $\begin{array}{r}0 \\
1 / 2 \\
1\end{array}$ & $\begin{array}{l}4 \cdot 92 \\
5 \cdot 17 \\
5 \cdot 20\end{array}$ & $5 \cdot 34$ & $\begin{array}{l}3 \cdot 61 \\
3 \cdot 72 \\
3 \cdot 73\end{array}$ & $3 \cdot 81$ & $\begin{array}{l}2 \cdot 15 \\
2 \cdot 20 \\
2 \cdot 21\end{array}$ & $2 \cdot 33$ & $\begin{array}{l}1.25 \\
1.26 \\
1.26\end{array}$ & $1 \cdot 37$ \\
\hline 35 & $\begin{array}{r}0 \\
1 / 2 \\
1\end{array}$ & $\begin{array}{l}6 \cdot 91 \\
7 \cdot 58 \\
7 \cdot 68\end{array}$ & $7 \cdot 95$ & $\begin{array}{l}5 \cdot 14 \\
5 \cdot 57 \\
5 \cdot 60\end{array}$ & $5 \cdot 86$ & $\begin{array}{l}3 \cdot 22 \\
3 \cdot 40 \\
3 \cdot 44\end{array}$ & $3 \cdot 68$ & $\begin{array}{l}2 \cdot 15 \\
2 \cdot 25 \\
2 \cdot 30\end{array}$ & $2 \cdot 50$ \\
\hline 40 & $\begin{array}{r}0 \\
1 / 2 \\
2 / 3\end{array}$ & $\begin{array}{r}9.40 \\
11.58 \\
11.96\end{array}$ & $12 \cdot 59$ & $\begin{array}{l}7 \cdot 60 \\
8 \cdot 86 \\
9 \cdot 10\end{array}$ & $9 \cdot 61$ & $\begin{array}{l}4.96 \\
5.91 \\
6.03\end{array}$ & $6 \cdot 42$ & $\begin{array}{l}3 \cdot 70 \\
4 \cdot 48 \\
4 \cdot 58\end{array}$ & $4 \cdot 84$ \\
\hline
\end{tabular}

$\mathrm{S}=$ after Soubra et al. (1999). 
The numerical results show a reduction in the passive earth pressure coefficient with a decrease in the dilation angle $\psi$ for large $\phi$ values. Hence one of the advantages of the present FLAC analysis is the possibility of taking into account in the computations the non-associative character of

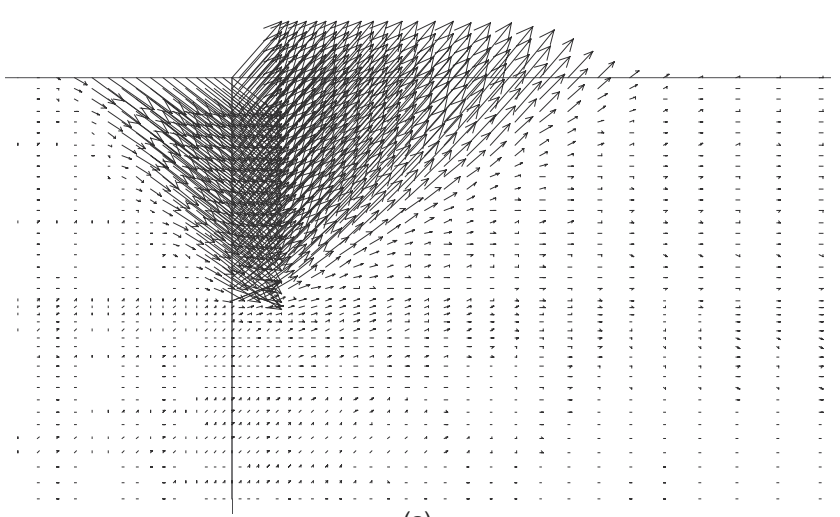

(a)

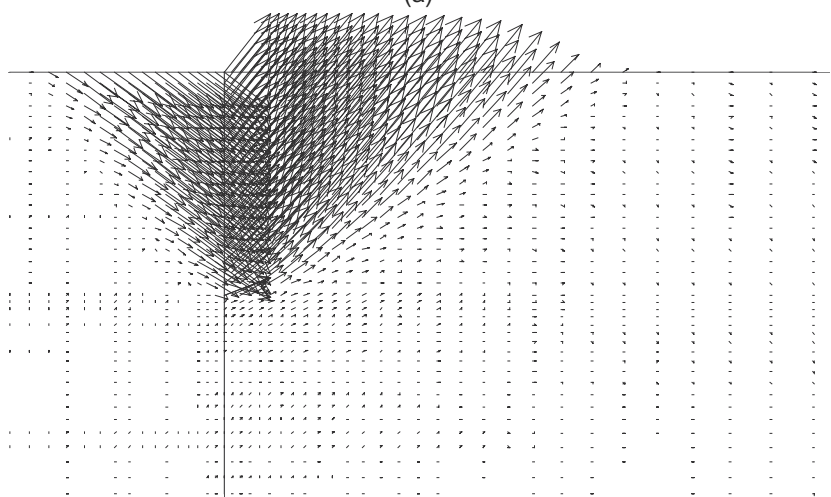

(b)

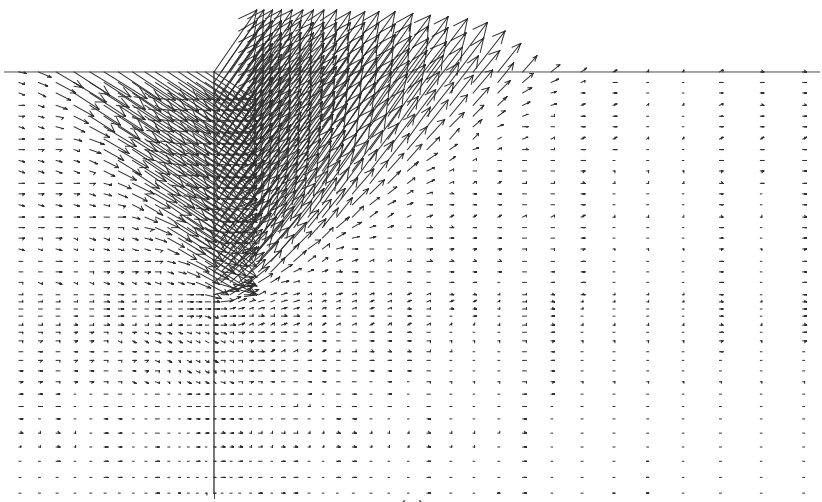

(c)

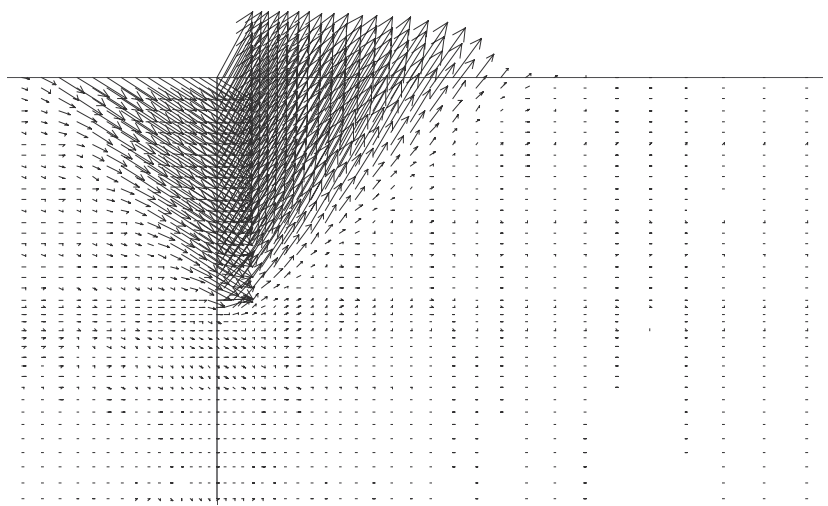

(d)

Fig. 6. Displacement fields for four values of $H / f$ when $\phi=35^{\circ}$, $\delta / \phi=0$ and $\psi / \phi=1 / 2$ : (a) $H / f=0$; (b) $H / f=1$; (c) $H / f=2$; (d) $H / f=2 \cdot 5$ the granular soils as observed experimentally. Tables 2, 3 and 4 also show a reduction in the passive earth pressure coefficient with an increase in the hydraulic head loss $H / f$. The reduction is most significant for small $\phi$ angles. For instance, when $\delta / \phi=2 / 3$ and $\psi / \phi=1 / 2$, the reduction is $61 \%$ for $\phi=40^{\circ}$ and $85 \%$ for $\phi=20^{\circ}$ when $H / f$ increases from zero to $2 \cdot 5$.

Figures 6-9 show respectively for two values of the interface friction angle $(\delta / \phi=0,2 / 3)$ the displacement field and the distribution of maximum shear strain rates, for four values of the hydraulic head loss $(H / f=0,1,2,2.5)$ when $\phi=35^{\circ}$ and $\psi / \phi=1 / 2$.

For $\delta / \phi=0$ the failure surface is similar to the planar surface proposed by Rankine (1857). However, for $\delta / \phi=2 /$ 3 the failure mechanism is similar to the Prandtl mechanism
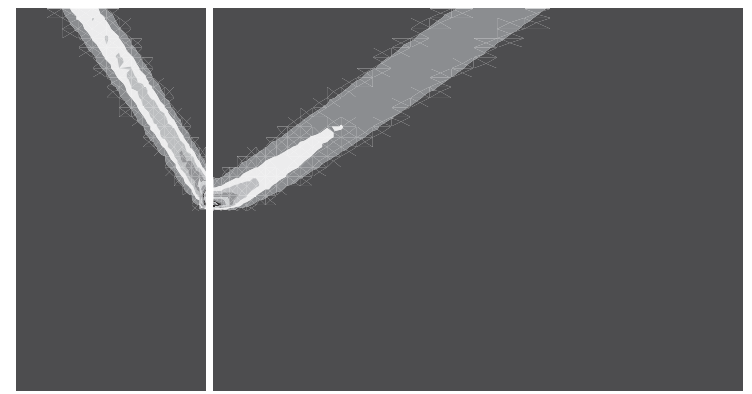

(a)
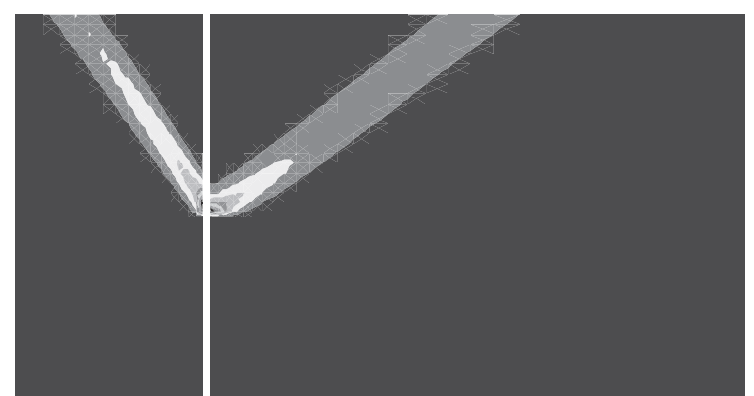

(b)
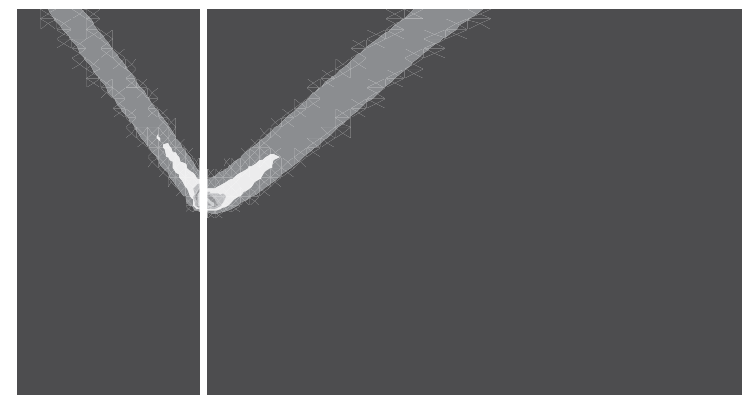

(c)
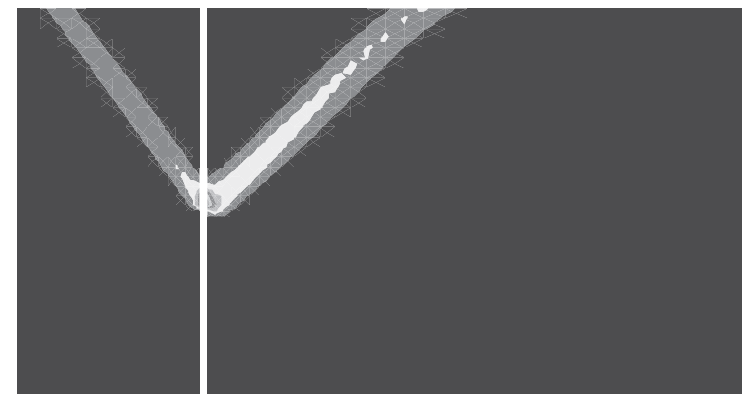

(d)

Fig. 7. Distribution of maximum shear strain rates for four values of $H / f$ when $\phi=35^{\circ}, \delta / \phi=0$ and $\psi / \phi=1 / 2$ : (a) $H / f=0$; (b) $H / f=1$; (c) $H / f=2$; (d) $H / f=2 \cdot 5$ 


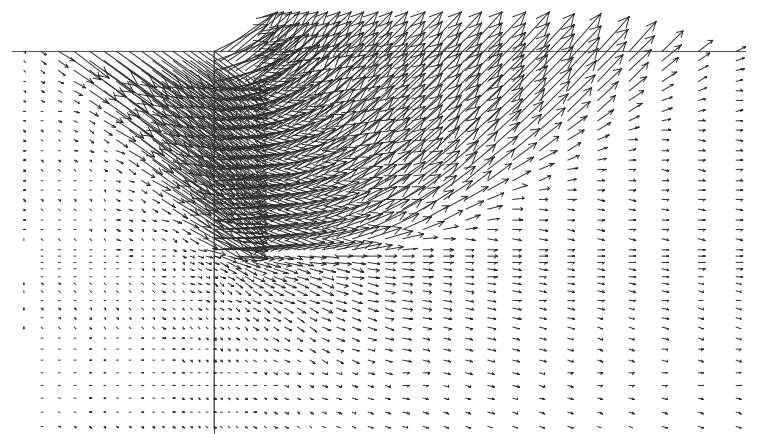

(a)

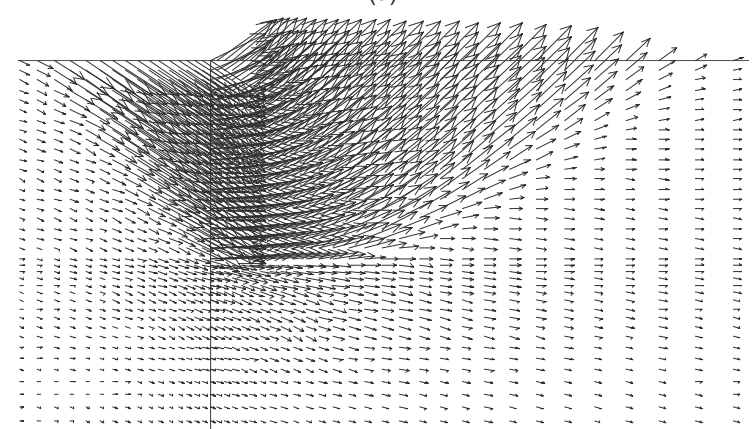

(b)

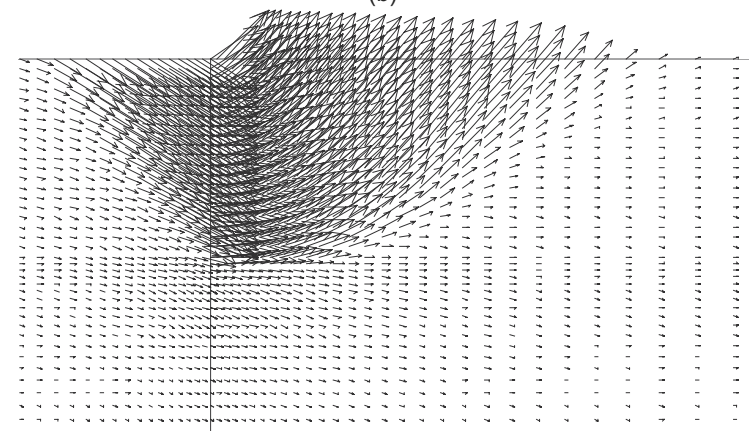

(c)

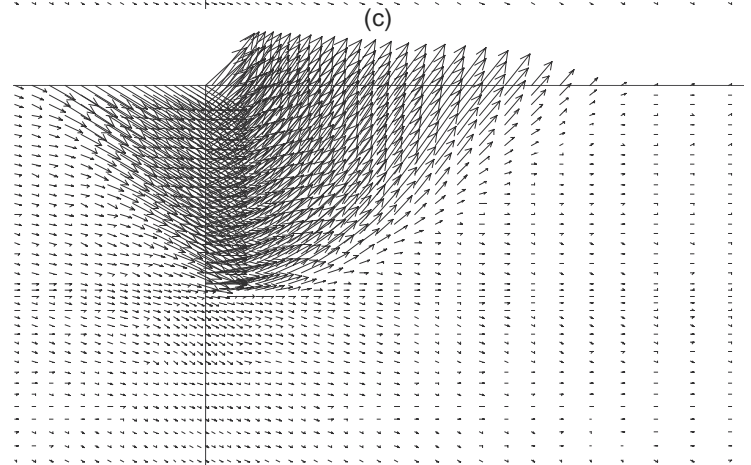

(d)

Fig. 8. Displacement fields for four values of $H / f$ when $\phi=35^{\circ}$, $\delta / \phi=2 / 3$ and $\psi / \phi=1 / 2$ : (a) $H / f=0$; (b) $H / f=1$; (c) $H / f=2$; (d) $H / f=2 \cdot 5$

with a radial shear zone followed by a Rankine passive wedge (Prandtl, 1921). These figures also show that the pore water pressures generated by seepage flow shift the failure surface to less favourable positions. The failure mechanism becomes less extended as the hydraulic head loss increases.

\section{Active case}

Tables 5, 6 and 7 give the effective active earth pressure coefficient $K_{\mathrm{a}}$ for three different values of the interface friction angle $(\delta / \phi=0,1 / 3,2 / 3)$. In each table the active earth pressure coefficient is given for four values of the
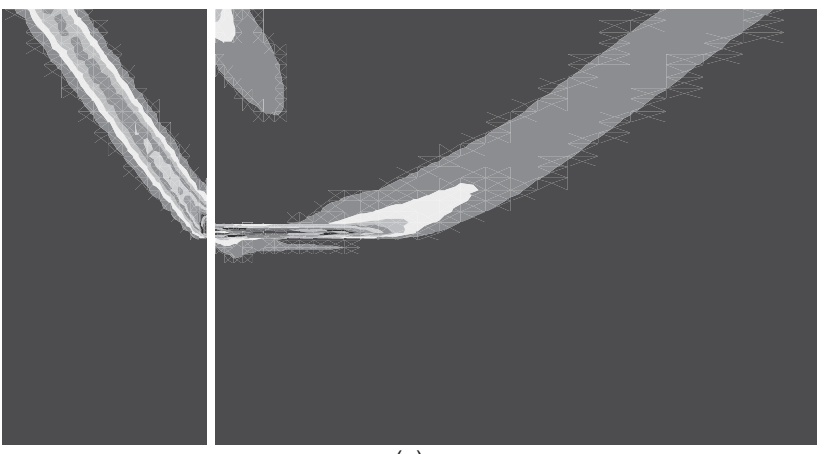

(a)
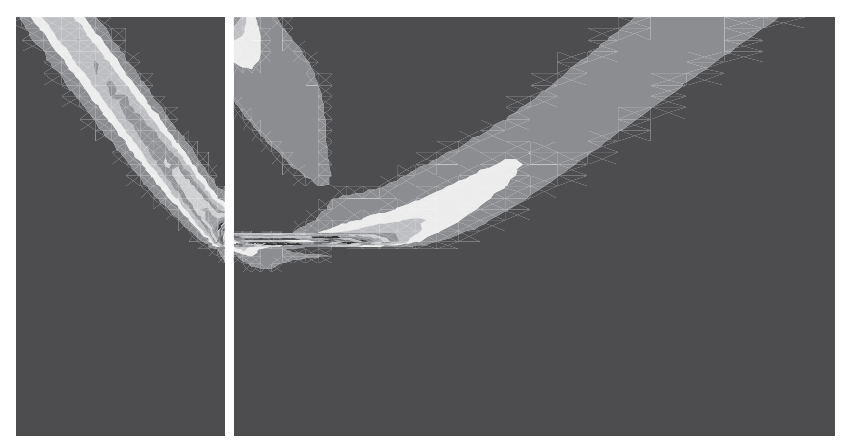

(b)
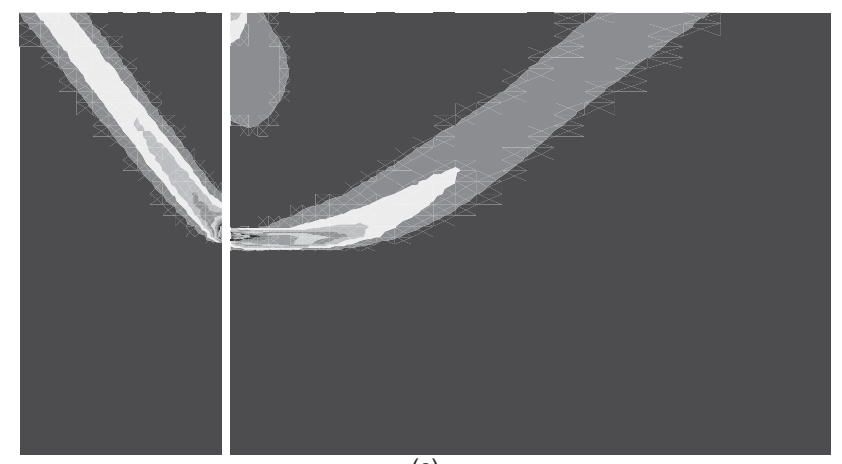

(c)
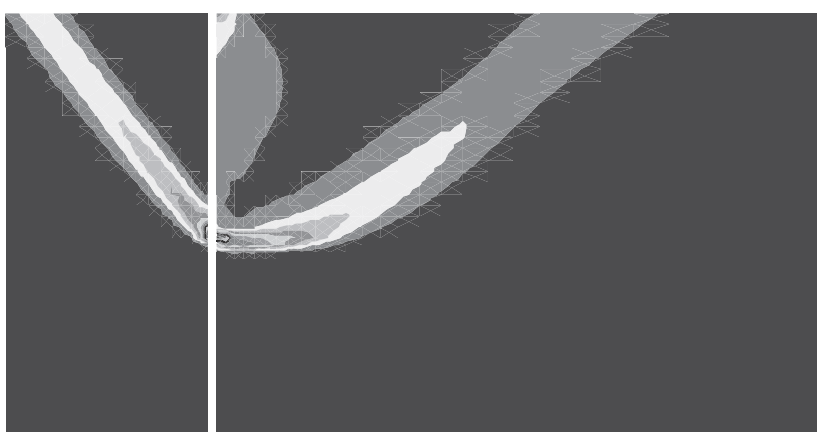

(d)

Fig. 9. Distribution of maximum shear strain rates for four values of $H / f$ when $\phi=35^{\circ}, \delta / \phi=2 / 3$ and $\psi / \phi=1 / 2$ : (a) $H / f=$ 0; (b) $H / f=1$; (c) $H / f=2$; (d) $H / f=2 \cdot 5$

friction angle $\left(\phi=20^{\circ}, 30^{\circ}, 35^{\circ}, 40^{\circ}\right)$, for three values of the dilation angle $(\psi / \phi=0,1 / 2,2 / 3$ or 1$)$ and for four values of the hydraulic head loss $(H / f=0,1,2,2 \cdot 5)$.

These tables clearly show that the seepage forces increase the active earth pressure coefficient significantly. For instance, the increase is $89 \%$ when $H / f$ increases from 0 to 2 for $\phi=40^{\circ}, \delta / \phi=2 / 3$ and $\psi / \phi=2 / 3$. Also, it can be easily seen that the active earth pressure coefficient increases 
Table 5. Active earth pressure coefficient $K_{\mathrm{a}}$ for various governing parameters $\phi, \psi / \phi$, and $H / f$ when $\delta / \phi=0$

\begin{tabular}{|c|c|c|c|c|c|}
\hline \multirow[t]{2}{*}{$\phi:$ degrees } & \multirow[t]{2}{*}{$\psi / \phi$} & \multicolumn{4}{|c|}{$H / f$} \\
\hline & & 0 & 1 & 2 & $2 \cdot 5$ \\
\hline 20 & $\begin{array}{r}0 \\
1 / 2 \\
1\end{array}$ & $\begin{array}{l}0 \cdot 49 \\
0 \cdot 48 \\
0 \cdot 48\end{array}$ & $\begin{array}{l}0.69 \\
0.68 \\
0.67\end{array}$ & $\begin{array}{l}0.90 \\
0 \cdot 88 \\
0.88\end{array}$ & $\begin{array}{l}1 \cdot 00 \\
0 \cdot 97 \\
0.96\end{array}$ \\
\hline 30 & $\begin{array}{r}0 \\
1 / 2 \\
1\end{array}$ & $\begin{array}{l}0 \cdot 34 \\
0 \cdot 32 \\
0 \cdot 32\end{array}$ & $\begin{array}{l}0 \cdot 50 \\
0 \cdot 46 \\
0 \cdot 45\end{array}$ & $\begin{array}{l}0.65 \\
0.60 \\
0.59\end{array}$ & $\begin{array}{l}0.74 \\
0.68 \\
0.66\end{array}$ \\
\hline 35 & $\begin{array}{r}0 \\
1 / 2 \\
1\end{array}$ & $\begin{array}{l}0 \cdot 30 \\
0 \cdot 26 \\
0 \cdot 26\end{array}$ & $\begin{array}{l}0 \cdot 43 \\
0 \cdot 37 \\
0 \cdot 37\end{array}$ & $\begin{array}{l}0.55 \\
0 \cdot 49 \\
0.48\end{array}$ & $\begin{array}{l}0.61 \\
0 \cdot 54 \\
0.53\end{array}$ \\
\hline 40 & $\begin{array}{r}0 \\
1 / 2 \\
2 / 3\end{array}$ & $\begin{array}{l}0 \cdot 26 \\
0 \cdot 22 \\
0 \cdot 21\end{array}$ & $\begin{array}{l}0 \cdot 37 \\
0 \cdot 31 \\
0 \cdot 30\end{array}$ & $\begin{array}{l}0 \cdot 48 \\
0 \cdot 39 \\
0 \cdot 38\end{array}$ & $\begin{array}{l}0 \cdot 54 \\
0 \cdot 44 \\
0 \cdot 42\end{array}$ \\
\hline
\end{tabular}

Table 6. Active earth pressure coefficient $K_{\mathrm{a}}$ for various governing parameters $\phi, \psi / \phi$, and $H / f$ when $\delta / \phi=1 / 3$

\begin{tabular}{|c|c|c|c|c|c|}
\hline \multirow[t]{2}{*}{$\phi:$ degrees } & \multirow[t]{2}{*}{$\psi / \phi$} & \multicolumn{4}{|c|}{$H / f$} \\
\hline & & 0 & 1 & 2 & $2 \cdot 5$ \\
\hline 20 & $\begin{array}{r}0 \\
1 / 2 \\
1\end{array}$ & $\begin{array}{l}0.46 \\
0.46 \\
0.46\end{array}$ & $\begin{array}{l}0.63 \\
0.62 \\
0.62\end{array}$ & $\begin{array}{l}0 \cdot 80 \\
0 \cdot 80 \\
0 \cdot 80\end{array}$ & $\begin{array}{l}0.86 \\
0.85 \\
0.85\end{array}$ \\
\hline 30 & $\begin{array}{r}0 \\
1 / 2 \\
1\end{array}$ & $\begin{array}{l}0 \cdot 32 \\
0 \cdot 31 \\
0 \cdot 31\end{array}$ & $\begin{array}{l}0.44 \\
0.43 \\
0.42\end{array}$ & $\begin{array}{l}0.58 \\
0.55 \\
0.53\end{array}$ & $\begin{array}{l}0.65 \\
0.62 \\
0.61\end{array}$ \\
\hline 35 & $\begin{array}{r}0 \\
1 / 2 \\
1\end{array}$ & $\begin{array}{l}0.28 \\
0.26 \\
0.25\end{array}$ & $\begin{array}{l}0.37 \\
0 \cdot 34 \\
0.33\end{array}$ & $\begin{array}{l}0.50 \\
0.46 \\
0.45\end{array}$ & $\begin{array}{l}0.55 \\
0 \cdot 52 \\
0.50\end{array}$ \\
\hline 40 & $\begin{array}{r}0 \\
1 / 2 \\
2 / 3\end{array}$ & $\begin{array}{l}0 \cdot 24 \\
0 \cdot 21 \\
0 \cdot 20\end{array}$ & $\begin{array}{l}0.31 \\
0 \cdot 28 \\
0.26\end{array}$ & $\begin{array}{l}0.40 \\
0.37 \\
0.35\end{array}$ & $\begin{array}{l}0.43 \\
0.40 \\
0.37\end{array}$ \\
\hline
\end{tabular}

Table 7. Active earth pressure coefficient $K_{\mathrm{a}}$ for various governing parameters $\phi, \psi / \phi$, and $H / f$ when $\delta / \phi=2 / 3$

\begin{tabular}{|c|c|c|c|c|c|}
\hline \multirow[t]{2}{*}{$\phi:$ degrees } & \multirow[t]{2}{*}{$\psi / \phi$} & \multicolumn{4}{|c|}{$\mathrm{H} / \mathrm{f}$} \\
\hline & & 0 & 1 & 2 & $2 \cdot 5$ \\
\hline 20 & $\begin{array}{r}0 \\
1 / 2 \\
1\end{array}$ & $\begin{array}{l}0.44 \\
0.44 \\
0.44\end{array}$ & $\begin{array}{l}0.62 \\
0.62 \\
0.62\end{array}$ & $\begin{array}{l}0 \cdot 81 \\
0 \cdot 81 \\
0 \cdot 81\end{array}$ & $\begin{array}{l}0 \cdot 89 \\
0.86 \\
0.86\end{array}$ \\
\hline 30 & $\begin{array}{r}0 \\
1 / 2 \\
1\end{array}$ & $\begin{array}{l}0 \cdot 31 \\
0 \cdot 30 \\
0 \cdot 29\end{array}$ & $\begin{array}{l}0.45 \\
0.43 \\
0.42\end{array}$ & $\begin{array}{l}0.57 \\
0.54 \\
0.54\end{array}$ & $\begin{array}{l}0.61 \\
0.60 \\
0.59\end{array}$ \\
\hline 35 & $\begin{array}{r}0 \\
1 / 2 \\
1\end{array}$ & $\begin{array}{l}0 \cdot 25 \\
0 \cdot 24 \\
0 \cdot 23\end{array}$ & $\begin{array}{l}0 \cdot 35 \\
0 \cdot 31 \\
0 \cdot 30\end{array}$ & $\begin{array}{l}0.46 \\
0.44 \\
0.44\end{array}$ & $\begin{array}{l}0.52 \\
0.49 \\
0.48\end{array}$ \\
\hline 40 & $\begin{array}{r}0 \\
1 / 2 \\
2 / 3\end{array}$ & $\begin{array}{l}0.23 \\
0.20 \\
0.18\end{array}$ & $\begin{array}{l}0.33 \\
0.29 \\
0.26\end{array}$ & $\begin{array}{l}0.42 \\
0.37 \\
0.34\end{array}$ & $\begin{array}{l}0.46 \\
0.41 \\
0.38\end{array}$ \\
\hline
\end{tabular}


with the dilation angle decrease. The difference is $27 \%$ when $\psi / \phi$ decreases from $2 / 3$ to 0 for $\phi=40^{\circ}, \delta / \phi=2 / 3$ and $H / f=1$

\section{Comparison with the practical rule}

Figures 10 and 11 show the variation of the effective active and passive forces with the hydraulic head loss for the case study presented in Fig. 1 when $\phi=40^{\circ}, \delta / \phi=2 /$ $3, \psi / \phi=2 / 3, \gamma_{\text {sat }}=20 \mathrm{kN} / \mathrm{m}^{3}$ and $f=3 \mathrm{~m}$. These forces are calculated by direct FLAC simulation (Tables 4 and 7) and by the simplified practical rule presented earlier using the apparent soil unit weight and $K_{\mathrm{a}}$, and $K_{\mathrm{p}}$ from the same tables for the case without flow $(H=0)$.

It can be seen that, in the active case, the practical rule gives good results for the effective active earth force acting on the wall. However, in the passive case, this rule is very severe and greatly overestimates the reduction in the passive earth pressures, especially for large hydraulic head loss. For $H / f=2$ the practical rule gives zero passive force for every value of $\delta / \phi$; however, the results from FLAC analysis show that the soil gives a passive force, which increases with an increase of both $\phi$ and $\delta / \phi$.

\section{CONCLUSIONS}

Numerical computations of the passive and active earth pressures in the presence of seepage flow have been per-

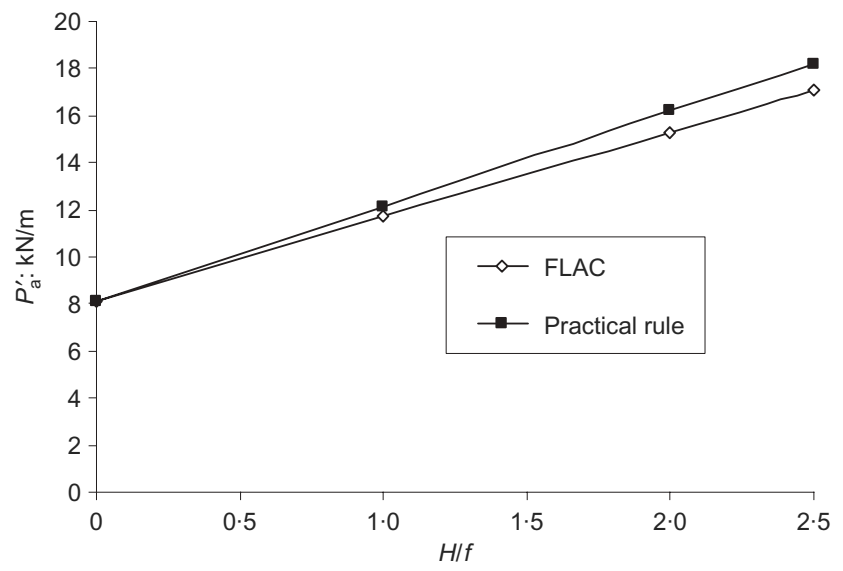

Fig. 10. Effective active force $P_{\mathrm{a}}^{\prime}$ against hydraulic head loss $H / f$ when $\phi=40^{\circ}, \delta / \phi=2 / 3, \psi / \phi=2 / 3, \gamma_{\text {sat }}=20 \mathrm{kN} / \mathrm{m}^{3}$ and $f=$ $3 \mathbf{m}$

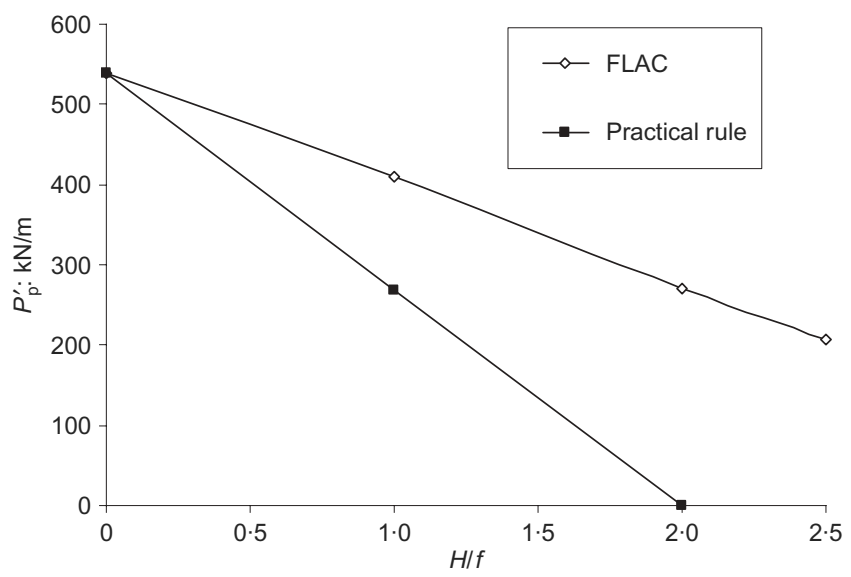

Fig. 11. Effective passive force $\boldsymbol{P}_{\mathrm{p}}^{\prime}$ against hydraulic head loss $\boldsymbol{H} /$ $f$ when $\phi=40^{\circ}, \delta / \phi=2 / 3, \psi / \phi=2 / 3, \gamma_{\mathrm{sat}}=20 \mathrm{kN} / \mathrm{m}^{3}$ and $f=$ $3 \mathrm{~m}$ formed using FLAC code. The solutions presented are given for associative and non-associative material.

The present numerical simulations of the effective passive earth pressures have shown the following.

(a) The passive earth pressures decrease with the hydraulic head loss. The reduction is most significant for small $\phi$ angles. For instance, when $\delta / \phi=2 / 3$ and $\psi / \phi=1 / 2$, the reduction is $61 \%$ for $\phi=40^{\circ}$ and attains $85 \%$ for $\phi=20^{\circ}$ when $H / f$ increases from zero to $2 \cdot 5$.

(b) The comparison between the upper-bound solutions given by Soubra et al. (1999) and the present results for $\psi=\phi$ shows good agreement: the difference does not exceed $9 \%$ for $H / f \leqslant 2$.

(c) The passive earth pressures decrease with a decrease in the dilation angle $\psi$ for large $\phi$ values.

(d) For $\delta / \phi=0$ the failure surface is similar to the planar surface proposed by Rankine. However, for $\delta / \phi=2 / 3$ the failure mechanism is similar to the traditional Prandtl mechanism, with a radial shear zone followed by a Rankine passive wedge. Also, it has been shown that the pore water pressures generated by seepage flow shift the failure surface to less favourable positions. The failure mechanism becomes less extended as the hydraulic head loss increases.

The present numerical simulations of the effective active earth pressures have shown the following.

(e) The seepage flow increases the active earth pressure coefficient significantly. For instance, the increase attains $89 \%$ when $H / f$ increases from 0 to 2 for $\phi=$ $40^{\circ}, \delta / \phi=2 / 3$ and $\psi / \phi=2 / 3$.

$(f)$ The active earth pressure coefficient increases with decrease in the dilation angle. It attains $27 \%$ when $\psi / \phi$ decreases from $2 / 3$ to 0 for $\phi=40^{\circ}, \delta / \phi=2 / 3$ and $H / f=1$.

The computation of the effective active and passive earth force acting on the sheet pile wall has shown that the simplified practical rule gives good results in the active case; however, it greatly overestimates the reduction in the passive soil resistance, especially for large hydraulic head loss.

\section{NOTATION}

$c$ soil cohesion

$f$ penetration depth of sheet pile

$G$ shear modulus of the soil

$H$ total hydraulic head loss

$i$ average hydraulic gradient along wall

$K$ bulk modulus of soil

$K_{\text {a }} \quad$ effective active earth pressure coefficient

$K_{\mathrm{n}}$ interface normal stiffness

$K_{\mathrm{s}} \quad$ interface shear stiffness

$K_{\mathrm{p}} \quad$ effective passive earth pressure coefficient

$p$ pore water pressure

$P_{a}^{\prime} \quad$ effective active force

$P_{\mathrm{p}}^{\prime} \quad$ effective passive force

$P_{\mathrm{p}^{\prime}}^{\prime}$ horizontal component of the effective passive force.

$\gamma^{\prime}$ submerged unit weight of soil

$\gamma_{\text {app }}^{\prime}$ apparent submerged unit weight of soil

$\gamma_{\text {sat }}$ saturated unit weight of soil

$\gamma_{\mathrm{w}}$ unit weight of water

$\delta$ angle of friction at soil/wall interface

$\phi$ angle of internal friction of soil

$\psi$ dilation angle of soil

\section{REFERENCES}

Banerjee, S. (1993). Design charts for double-walled cofferdams. J. Geotech. Engng ASCE 119, No. 2, 214-222.

Banerjee, S. \& Muleshkov, A. (1992). Analytical solutions for 
steady seepage into double-walled cofferdams. J. Engng Mech. ASCE 118, No. 3, 525-539.

Bazant, Z. (1963). Ergebnisse der Berechnung der Stabilitat gegen Hydraulischen Grundbruch mit Hilfe der Elektronen-Rechenanlage. Proc. Int. Conf. Soil Mech. Found. Engng, Budapest, 215-223.

Caquot, A. \& Kérisel, J. (1948). Tables de poussée et de butée. Paris: Gauthier-Villard.

Chen, W.F. \& Liu, X.L. (1990). Limit analysis in soil mechanics. Amsterdam: Elsevier.

Davidenkoff, R. N. \& Franke, O. L. (1965). Untersuchung der raumlichen Sickerstromung in eine umspundete Baugrube in offenen Gewassern. Die Bautechnik, 9, 298-307.

Erickson, H. L. \& Dresher, A. (2002). Bearing capacity of circular footings. J. Geotech. Geoenviron. Engng ASCE 128, No. 1, 38-43.

Fox, E. N. \& McNamee, J. (1948). The two-dimensional potential problem of seepage into cofferdam. Phil. Mag. 7, No. 39, $165-203$.

Frydman, S. \& Burd, H. J. (1997). Numerical studies of bearing capacity factor $N_{\mathrm{g}}$. J. Geotech. Geoenviron. Engng ASCE 123, No. 1, 20-29.

Graham, J. (1971). Calculation of passive pressure in sand. Can. Geotech. J. 8, No. 4, 566-579.

Harr, M. E. (1962). Groundwater and seepage. New York: McGraw-Hill.

Harr, M. E. \& Deen, R. C. (1961). Analysis of seepage problems. J. Soil Mech. Found. Div. ASCE 87, No. SM5, 91-107.

Itasca (2000). FLAC: Fast Lagrangian Analysis of Continua. Minneapolis: Itasca Consulting Group, Inc.

Kastner, R. (1982). Excavations profondes en site urbain: Problèmes liés à la mise hors d'eau. Dimensionnement des soutènements butonnés. DSc thesis, INSA Lyon and Claude Bernard University.

Kérisel, J. \& Absi, E. (1990). Tables de poussée et de butée des terres, 3rd edn. Paris: Presses de l'Ecole Nationale des Ponts et Chaussées.
King, G. J. W. \& Cockroft, J. E. M. (1972). The geometric design of long cofferdams. Géotechnique 22, No. 4, 619-633.

Lysmer, J. (1970). Limit analysis of plane problems in soil mechanics. J. Soil Mech. Found. Div. ASCE 96, No. SM4, 13111334.

Marsland, A. (1953). Model experiments to study the influence of seepage on the stability of a sheeted excavation in sand. Géotechnique 3, No. 6, 223-241.

McNamee, J. (1949). Seepage into a sheeted excavation. Géotechnique 1, No. 4, 229-241.

Prandtl, G. (1921). Eindringungsfestigkeit and festigkeit von sneiden, Angew. Math. U. Mech. 15, 1

Rahardjo, H. \& Fredlund, D. G. (1984). General limit equilibrium method for lateral earth forces. Can. Geotech. J. 21, No. 1, $166-175$.

Rankine, W. J. M. (1857). On the stability of loose earth. Trans. Royal Soc. 147, 9-27.

Shields, D. H. \& Tolunay, A. Z. (1972). Passive pressure coefficients for sand by the Terzaghi and Peck method. Can. Geotech. J. 9, No. 4, 501-503.

Shields, D. H. \& Tolunay, A. Z. (1973). Passive pressure coefficients by method of slices. J. Geotech. Engng Div. ASCE 99, No. SM12, 1043-1053.

Sokolovski, V. V. (1965). Statics of granular media. New York: Pergamon.

Soubra, A.-H. (2000). Static and seismic passive earth pressure coefficients on rigid retaining structures. Can. Geotech. J. 37, No. 2, 463-478.

Soubra, A.-H. \& Macuh, B. (2002). Active and passive earth pressure coefficients by a kinematical approach. Proc. Instn Civ. Engrs Geotech. Engng 155, No. 2, 119-131.

Soubra, A.-H., Kastner, R. \& Benmansour, A. (1999). Passive earth pressures in the presence of hydraulic gradients. Géotechnique 49, No. 3, 319-330.

Terzaghi, K. (1943). Theoretical soil mechanics. New York: Wiley. 